\title{
Diseases and Non-Battle Injuries (DNBI) in HUN Missions Based on EPIHUN Reports
}

\author{
SVÉD László, ${ }^{1}$ SÓTÉR Andrea, ${ }^{2}$ VEKERDI Zoltán ${ }^{3}$
}

\begin{abstract}
The Medical Service of the Hungarian Defence Forces (HDF) has been playing and taking an important role in the elimination and medical stabilization of several regional crisis areas since 1991. These medical protection and "back-ups" literally mean the medical support of our military forces take part in different tasks besides this fulfilling the special tasks of preventive medicine. The medical data collected from the different tasks and missions have been gathered systematically in order to be informative. From 2008 on we manage data collection with a real-time surveillance report system, the so called EPIHUN (Hungarian Epidemiological and Patient Turnover Report), which have been collected from different aspects and analysed from force health protection aspects. With the DNBI data from the system the authors are analysing the preventable diseases morbidity state and tendencies of the EUFOR (European Union Force), KFOR (Kosovo Force), MFO (Multinational Force and Observers) and UNFICYP (United Nations Peacekeeping Force in Cyprus) missions on a 2013 data base. It could be surprising that the morbidity data are very similar to the values seen among military collectives living in barracks during the conscription era of the armed forces. Most DNBI are acute respiratory diseases and diseases of the digestive system, which is important information in medical preparation training before deployment.
\end{abstract}

Keywords: Force health protection, Hungarian epidemiological and patient turnover report, medical service, Hungarian Defence Forces, analysis of preventable diseases morbidity

\section{Introduction}

The HDF and its Medical Service have been participating in almost every peace keeping and peace support operations in crisis areas all over the world since 1991. In some missions, the Hungarian forces were deployed with their own medical personnel, such as Gulf War I, in AFOR, or the Theatre Preventive Medicine Laboratory in KFOR, furthermore the Multinational Military Hospital in Afghanistan. In other missions, Hungarian medical personnel provided and still supply medical support for multinational forces.

In this article our analysis focuses on non-battle related disease data from EUFOR, KFOR, MFO, and UNFICYP troops' medical indices since 2013. In Afghanistan, a small number of Hungarian troops were imbedded into multinational formations, and their medical support was not provided by Hungarian medical personnel, therefore we have no data processing of these Hungarian contingents.

1 Lieutenant General (ret.), MD Ph.D.

2 Lieutenant Colonel, Ph.D.

3 Colonel, MD, Hungary, Budapest, HDF Medical Centre, E-mail: vekerdi.zoltan@hm.gov.hu 
SVÉD L., SÓTÉR A., VEKERDI Z.: Diseases and Non-Battle Injuries (DNBI) in HUN Missions...

Continuous health status monitoring of the personnel both in Hungary and in deployment is a priority area within force health protection tasks for the HDF Medical Service. The Hungarian real-time surveillance system - called EPIHUN - provides deployment health information on a weekly basis. Based on this information it is possible to monitor continuously the actual health status of personnel on deployment. Using validated criteria based on standardized definitions, unified methods and procedures; this system allows data collection, analysis, feedback and also intervention, if necessary.

By certain features we have started collecting data already from Gulf War I. Regarding this period we have obviously focussed especially on combat casualties and their distribution. (Table 1.) However these data also allow the drawing of some conclusions, but - as indicated already in many other analyses - the low number of casualties probably prevent making objective conclusions. Despite this, it is clearly seen here, how comparable the data of casualties treated by Hungarians in Gulf War I and World War II or the Vietnam War are. (Table 1.)

Table 1. Casualties treated by Hungarian medical personnel. [5]

\begin{tabular}{|c|c|c|c|}
\hline $\begin{array}{l}\text { Period } \\
\text { Injury location } \\
\end{array}$ & $\begin{array}{c}\text { Gulf War/ casualties } \\
\text { treated by HLNs } \\
\%\end{array}$ & $\begin{array}{c}\text { World War II. } \\
\%\end{array}$ & $\begin{array}{c}\text { Vietnam War } \\
\%\end{array}$ \\
\hline Complex & 8,6 & 11 & 20 \\
\hline Head & 17,2 & 12 & 14 \\
\hline Chest & 6 & 8 & 5 \\
\hline Abdomen & 4,4 & 4 & 5 \\
\hline Upper extremities & 30 & 26 & 18 \\
\hline Lower extremities & 24,2 & 39 & 36 \\
\hline Liver & 1,3 & \multirow{4}{*}{$\begin{array}{l}\text { Experience } \\
\text { based }\end{array}$} & $\rightarrow 16 \%$ \\
\hline Spleen & 3 & & $6 \%$ \\
\hline Pancreas & 1,3 & & $5 \%$ \\
\hline Burn injuries & 4,2 & & $3,7 \%$ \\
\hline
\end{tabular}

Table 2. Comparative analysis of injury types from WWII [7]

\begin{tabular}{|l|l|l|}
\hline Total number of casualties & 44 persons & $\begin{array}{l}\text { Injured during air operations } 15 \\
\text { persons }\end{array}$ \\
\hline Operations performed & 70 persons & $\begin{array}{l}\text { Injured during land operations15 } \\
\text { persons }\end{array}$ \\
\hline Died after treatment & 2 persons & $\begin{array}{l}\text { Injured during temporary truce } 6 \\
\text { persons }\end{array}$ \\
\hline
\end{tabular}

It is important to note that all operational movements had medical support. The medical support plan was mission tailored to the type of operational activity. Preliminary calculations of the numbers of casualties are an important part of the medical support plan. Casualty calculations have two parts, one is battle casualties (BC) and the other is diseases and non-battle 
SVÉD L., SÓTÉR A., VEKERDI Z.: Diseases and Non-Battle Injuries (DNBI) in HUN Missions...

injuries (DNBI). In the battle casualty (BC) categories are: killed in action (KIA), missing in action (MIA), captured in action (CIA), wounded in action (WIA), died of wound (DOW) and battle stress casualties (BSC). [7]

The main question is: why do we not deal at all with non-battle injuries? Why do we not analyse combat casualties and deaths of Hungarian contingents? Well, to tell the truth Hungary is extremely lucky from this point. There were only 8 persons who died in operations (out of them 5 KIA, 2 DOW and one died of non-enemy action - all of them served in Provincial Reconstruction Team missions in Afghanistan); and 20 other battle injuries since 1991, according to definitions described in NATO Allied Joint Medical Publication-1 (AJMedP-1). The final goal of our analysis is to underline the importance of these disease types.

\section{Implemented Methods and Terminology}

The NATO electronic epidemiological reporting system (EPINATO) integrated all the treatment criteria, like data on medical personnel, patient turnover data, information on medical equipment and consumables. This reporting system had to be adjusted to Hungarian conditions, which led to development of the so called EPIHUN reporting system. The first Hungarian Epidemiological and Patient Turnover Report (in 2003) was a paper-based reporting system, but from 2008 (by instruction of the Hungarian Surgeon general) it became recordable also electronically. The data from all different theatres became visible for medical experts in Hungary in almost real time. Deployed medical personnel of the Hungarian units provide these data for medical staff in the Joint Force Command to the Office of the Surgeon General, where these data are processed and analysed.

The EPIHUN reporting and data processing system applicable regulations are based on STANAG 2535 [6], AMedP-21, [1] - Deployment Health Surveillance and the 253/2008 Instruction of the Hungarian Surgeon General about casualty data reporting of deployed personnel. [2]

Reporting requirements and data processing: data reported by deployed Hungarian medical personnel

- EUFOR (Bosnia-Herzegovina)

- KFOR (Kosovo)

- MFO (Sína El-Gorah)

- UNFICYP (Cyprus)

Population at Risk 145 people

Population at Risk 180 people

Population at Risk 26 people

Population at Risk 77 people

In order to analyse frequency of non-battle diseases, we have used patient turnover databases of EPIHUN reports from 2013. After synchronizing these figures we generated a database. We used Microsoft Excel 2007 for analysing the given data and creating the tables. In the course of the analysis we defined the below listed indices:

a) calculating the distributional ratio of morbidity, with which we analysed the conformation of diseases in different missions;

b) analysis of data regarding referrals for specialized care, which is indicative for the percentage of definitive treatment provided by general practitioners (only a few patients were referred for consultation, which shows that initial diagnosis by the general practitioners was correct). 
SVÉD L., SÓTÉR A., VEKERDI Z.: Diseases and Non-Battle Injuries (DNBI) in HUN Missions...

The International Classification of Diseases (also known by the abbreviation ICD) provides data about the causes of requisition of the primary health care, along with the confirmation of diseases in different missions.

The data collection is continuous in every mission since Gulf War I, and focuses on systematization and definition of criteria for their implementation. However, it is possible only after the displayed regulations which were issued.

Before making conclusions based on these data, it is necessary to define the terms of incidence and prevalence. Incidence is the number of occurrence of new diseases in a population within a specified period of time (usually within a year). Prevalence is the total number of cases (diseases) in a population within a specified period of time.

Patient turnover data are regularly reported. They do not contain personal or sensitive medical information. The computer program allows easier data recording, categorization of archived disease cases, fast and complex data management. There is no legal obstacle for public releasing of these data.

\section{Results}

In epidemiological analyses it is important to review similarities and differences of conditions. It is essential to assess e.g. differences due to variant geographical locations and their impact on disease prevalence. Two of the four missions shown in Figure 1, have similar prevalence values to the ones found in Hungary, while the other two missions are different, having either positive or negative impact on disease incidence with their Mediterranean, even desert-like climate and geographical environment. We have analysed the impact of thermal stress on disease evolution in each mission. We have not yet analysed the Provincial Reconstruction Team mission in Afghanistan, as it was completed just last year.

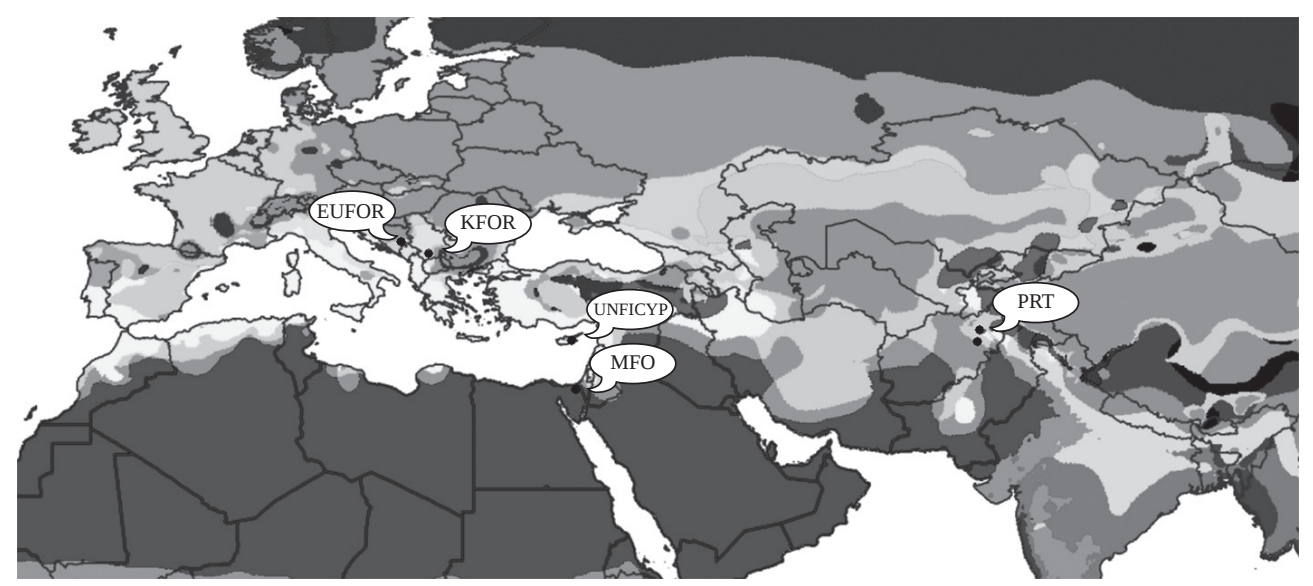

Figure 1. Geographical location of HUN missions. [Edited by the authors.] 


\section{Patient Turnover Data by Missions}

In EUFOR, the most prominent cases were the acute respiratory diseases (27\%), bone, muscle and connective tissue diseases (23.5\%) and dermatological cases (16\%). These three groups of diseases were responsible for $75 \%$ of the total patient turnover in EUFOR.

The climate of Sarajevo does not considerably differ from the climate in Hungary. Distribution of diseases therefore is also similar. We detected increased number of acute respiratory diseases when the weather is changing and the temperature decreasing. Dermatological diseases on the contrary appear in warmer periods. (Graph 1.)

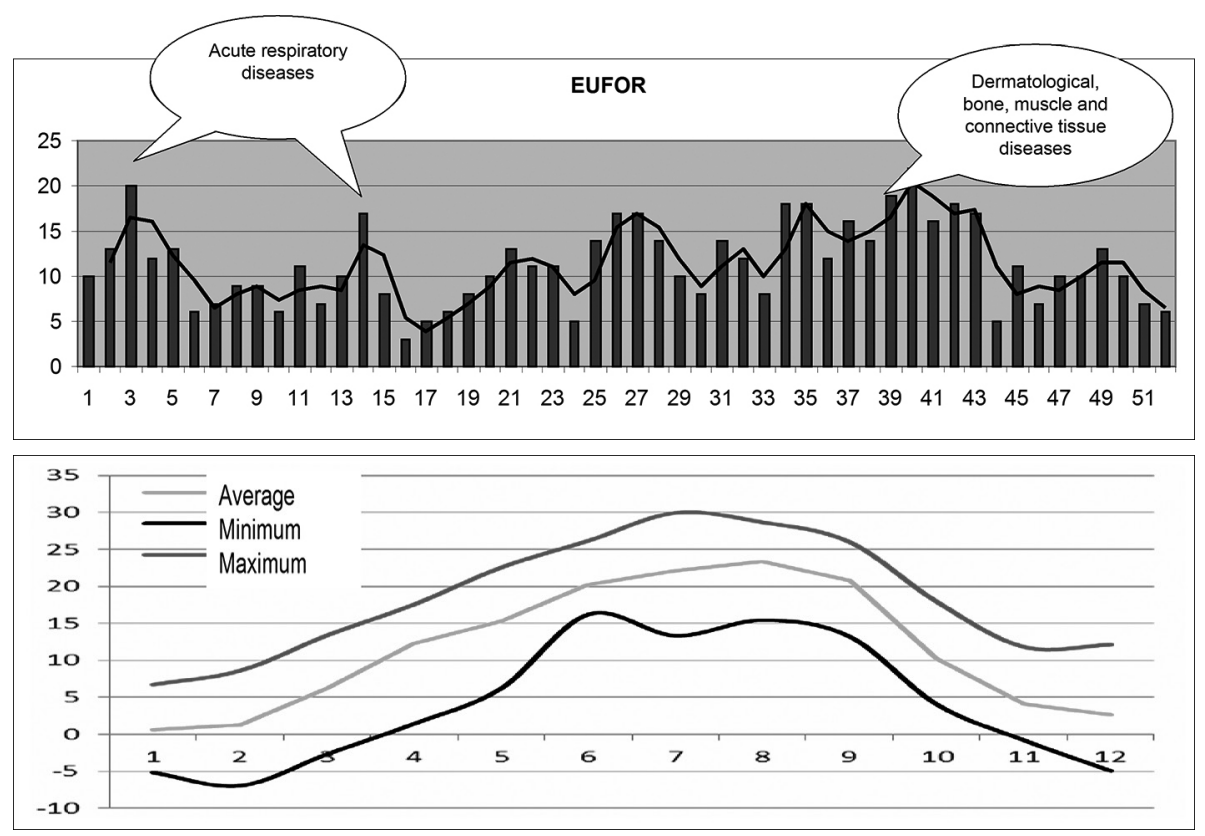

Graph 1. EUFOR total cases per weeks. [8]

In KFOR, 43\% of diseases were coded as "any other disease”, which from an epidemiological point of view cannot be evaluated. Acute respiratory cases are responsible for $16.8 \%$ of diseases, oral cavity, saliva gland and lower jaw diseases appeared in $13.4 \%$ of cases. The climate of Kosovo is also similar to the climate of Hungary. Increase in acute respiratory diseases can be explained by drops in temperature. (Graph 2.) 
SVÉD L., SÓTÉR A., VEKERDI Z.: Diseases and Non-Battle Injuries (DNBI) in HUN Missions...
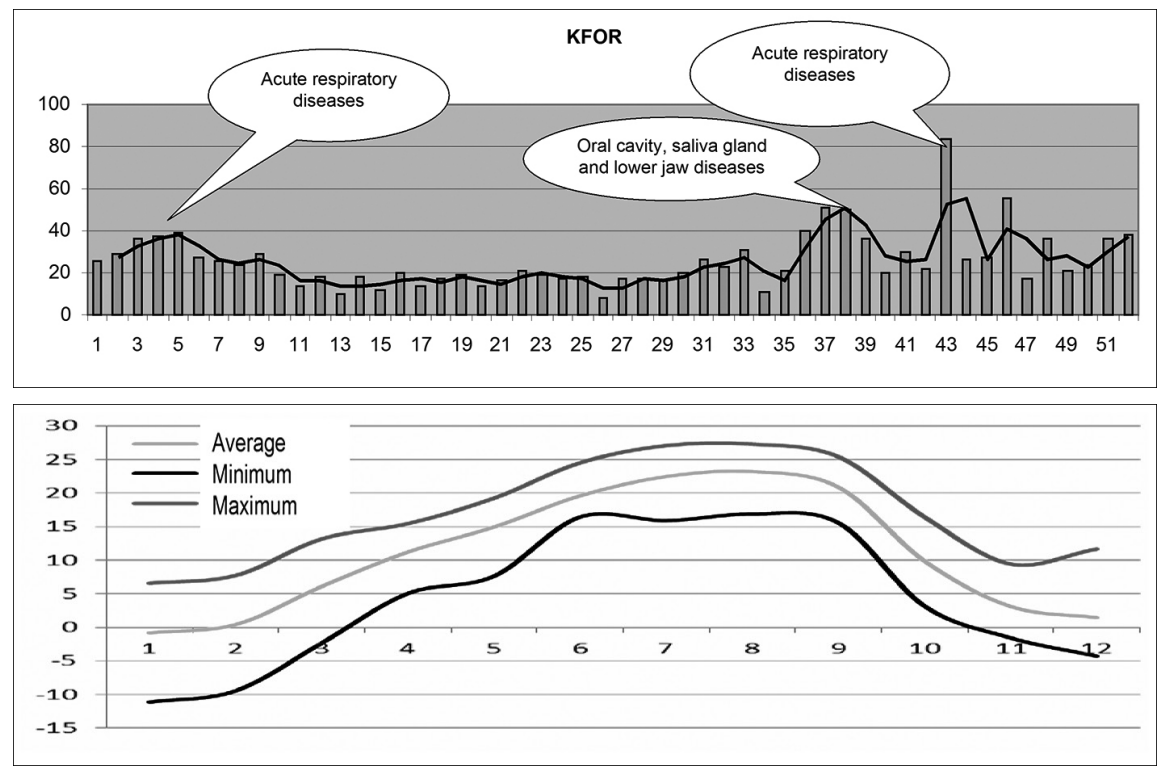

Graph 2. KFOR total cases per weeks. [8]

Only 20\% of the total number of patients were Hungarians in MFO. The most frequent cases were "any other diseases", counting 32\%, acute respiratory diseases, counting 17\%, infectious gastro-enteral and dermatological diseases; both appeared in $9 \%$ of cases. The part of "any other diseases" is too high, and it provides only vague information. High temperatures in desert climate conditions can be held responsible for infectious gastro-enteral and other diseases of the digestive system. There were no reports on epidemics. (Graph 3.)

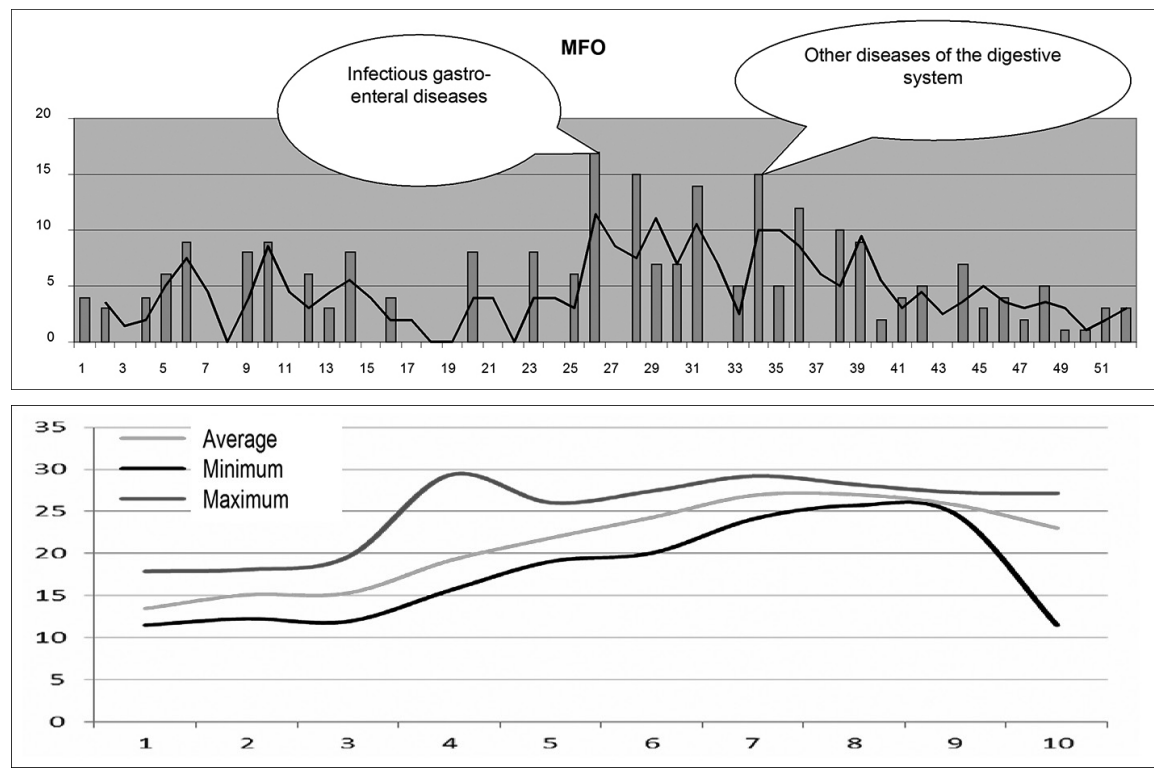

Graph 3. MFO total cases per weeks. [8] 
Among UNFICYP Hungarian personnel, acute respiratory diseases were the most frequent cases (39\%), bone, muscle and connective tissue diseases were found in 16\% of cases, and dermatological problems in $11.7 \%$ of cases. Increase in acute respiratory diseases can also be connected to the changes of weather. It is worth noting that case numbers jumped up before rotation, and were low during the acclimation period, and returned to seasonality afterwards. (Graph 4.)
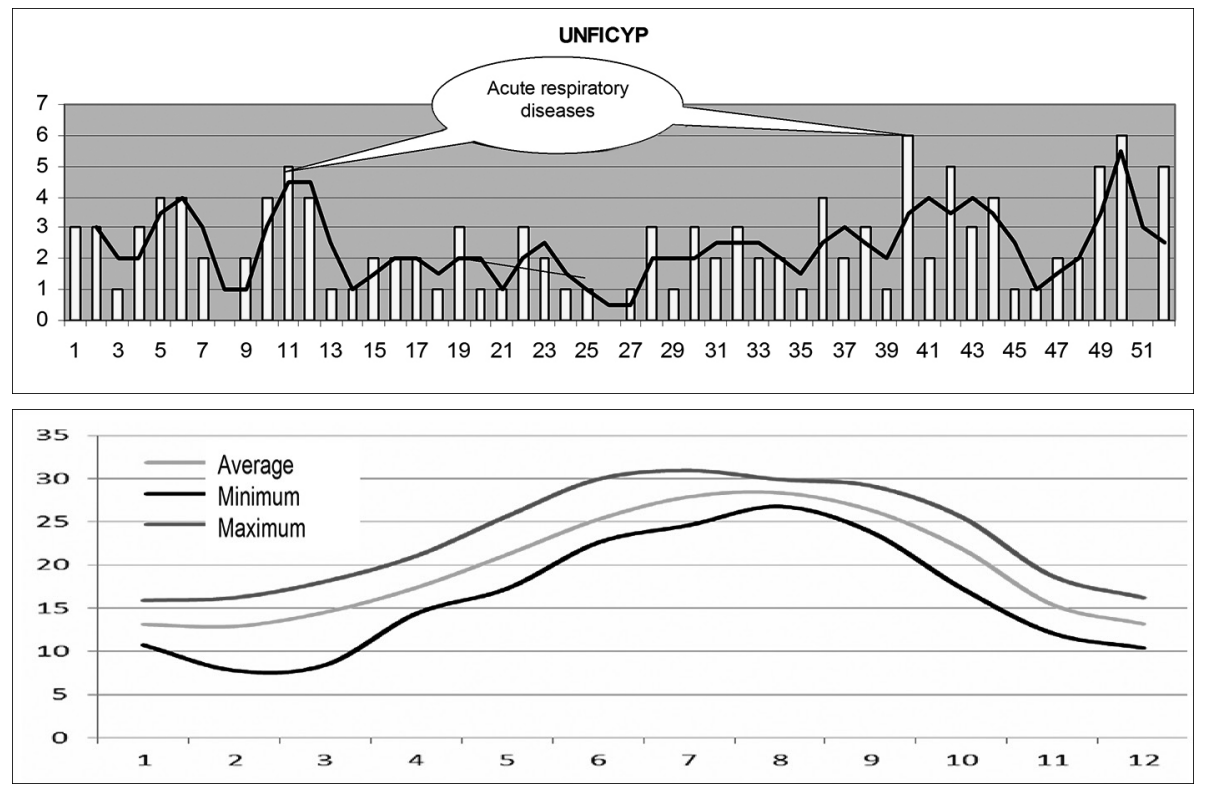

Graph 4. UNFICYP total cases per weeks. [8]

In Chart 2 we show the percentage of first appearance in light of the total number of participants. It is derived from patient turn over data in different missions. The values in italics refer to handover periods. The exception is the MFO mission, because we could confirm that their disease incidence grew during the acclimation period due to stress caused by adaptation challenges to new tasks, and also due to the changes in climate and environment. There is another exception also found in the MFO mission. Certain seasonality can be detected during winter-spring and autumn months also. The difference might be explained, if we take into consideration the low number of MFO participants, which result in low relative numbers. (Table 3.)

Table 3. The percentage of incidence (first appearance) ratio of missions per first medical contact in monthly statistics in 2013. [8]

\begin{tabular}{|c|c|c|c|c|c|c|c|c|c|c|c|c|c|}
\hline iss & Jan & Febr & arch & Apr & $y$ & in & ly & ug & ept & Oct & ov & ec & al \\
\hline $\mathrm{MFO}$ & 61, & 50,0 & $146,2 \%$ & $53,8 \%$ & $65,4 \%$ & $50,0 \%$ & $7,7 \%$ & $42,3 \%$ & $46,2 \%$ &, 5 & $80,8 \%$ & $23,1 \%$ & 179 \\
\hline UNF & 11,7 & 10 & $20,8 \%$ & $19,5 \%$ & $\%$ & $10,4 \%$ & $8,2 \%$ & $\%$ & $14,3 \%$ & $\%$ & $6,5 \%$ & $\%$ & 143 \\
\hline EUF & 4 & $\%$ & $8 \%$ & $38,6 \%$ & $43,5 \%$ & $43,5 \%$ & $64,8 \%$ & $32,4 \%$ & $13,8 \%$ & $11,7 \%$ & $9,0 \%$ & $4 \%$ & 627 \\
\hline 00 & $46,7 \%$ & $51,0 \%$ & $53,3 \%$ & $32,8 \%$ & $30,6 \%$ & $23,3 \%$ & $22,8 \%$ & $60,6 \%$ & $53,9 \%$ & $55,5 \%$ & $38,3 \%$ & $48,9 \%$ & 932 \\
\hline ( & 179 & 175 & 212 & 144 & 147 & 126 & 151 & 184 & 140 & 46 & 108 & 169 & 1881 \\
\hline
\end{tabular}


SVÉD L., SÓTÉR A., VEKERDI Z.: Diseases and Non-Battle Injuries (DNBI) in HUN Missions...

The percentage of first contacts in light of the total number of participants, derived from patient turn over data in different missions. Seasonality is seen in winter-spring and autumn period as well. We can see the patient turnover data by weeks listed in Graph 5.

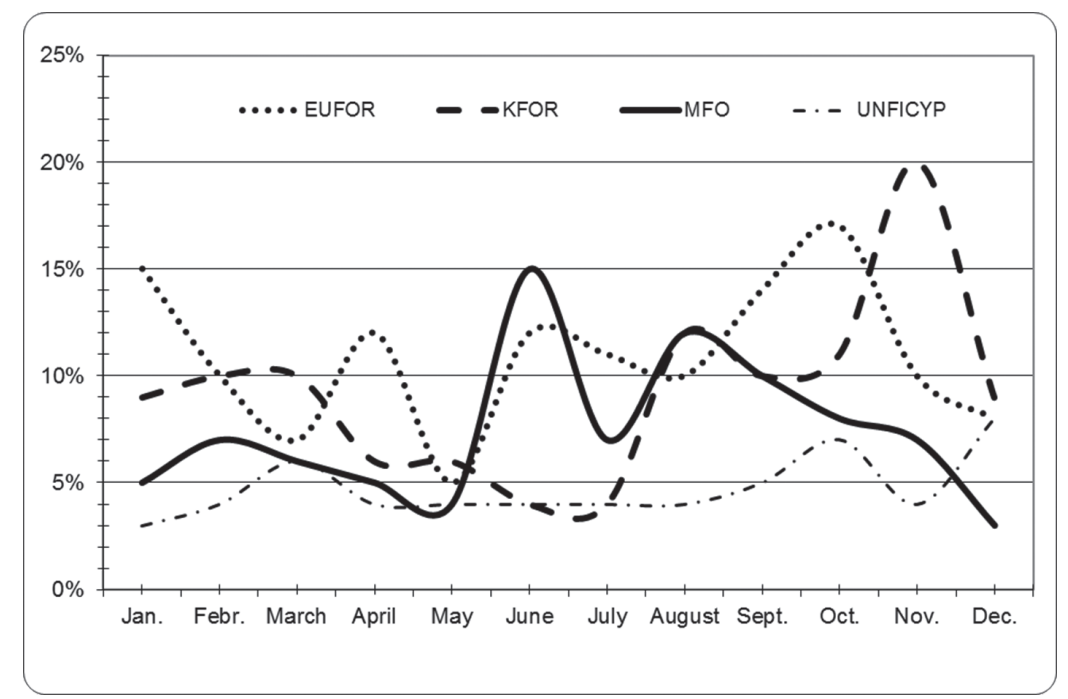

Graph 5. Missions of treatment statistics by months in 2013. [8]

On Graph 6. we show the patient turnover data by missions. It seems that in most cases definitive treatment was possible during first appearance already. A fewer number of patients are called back for control, and even a smaller number is referred to specialists. Only one patient was sent to hospital, both in MFO and UNFICYP.

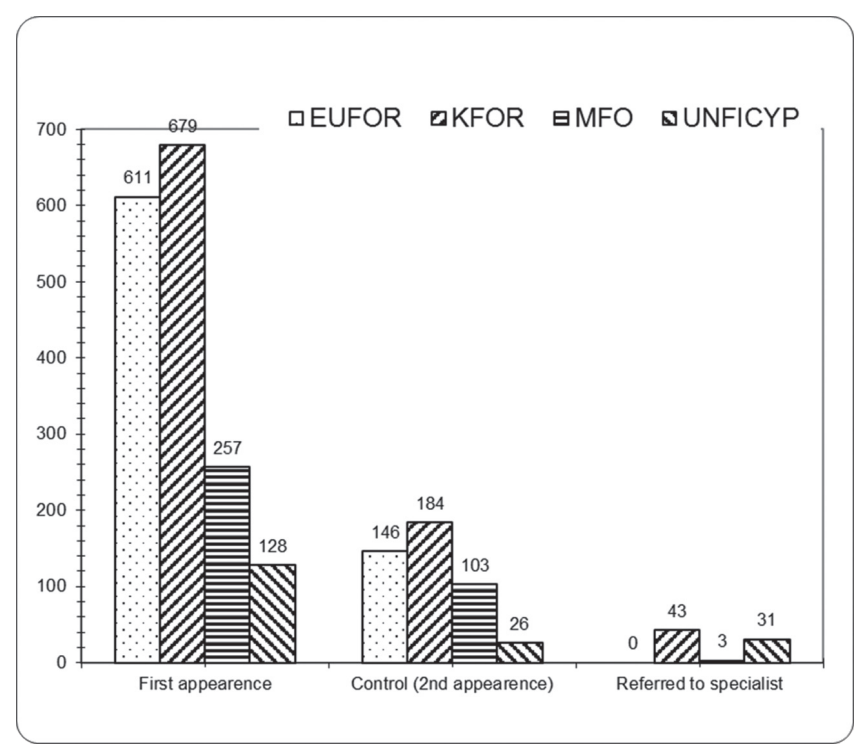

Graph 6. Treatment statistics by different missions in 2013. [8] 
Acute respiratory diseases are the most frequent cases in almost every mission, and the low temperature is responsible for it. Bone, muscle and connective tissue diseases are related to sport and other physical activities. The relevance of our analysis is weakened by high share of "any other diseases.” (Graph 7.)

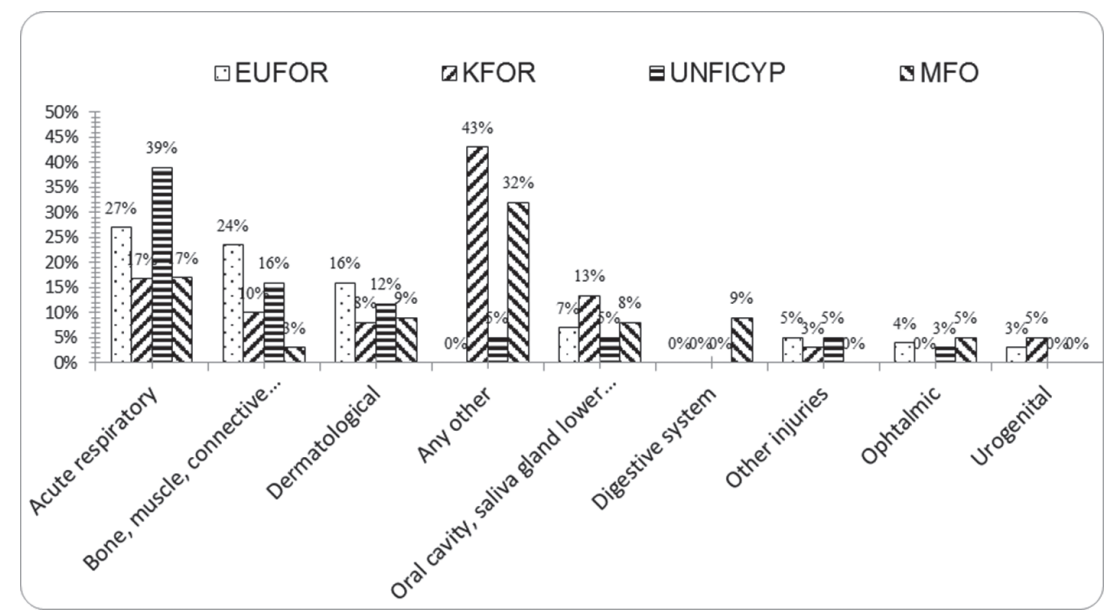

Graph 7. Disease structure by missions. [8]

Comparison of data from deployments and at home provides valuable information for pre-deployment planning. On this slide we show the homeland data of the same age groups as on deployment. Our conclusion is that there is no significant difference in disease structure on deployment (among the analysed missions) and at home. The most frequent cases among the military personnel at home duty stations are also the ones which require acute treatment. [4] The leading causes proved to be: acute respiratory diseases; bone, muscle and connective tissue diseases; and infectious diseases. (Graph 8.)

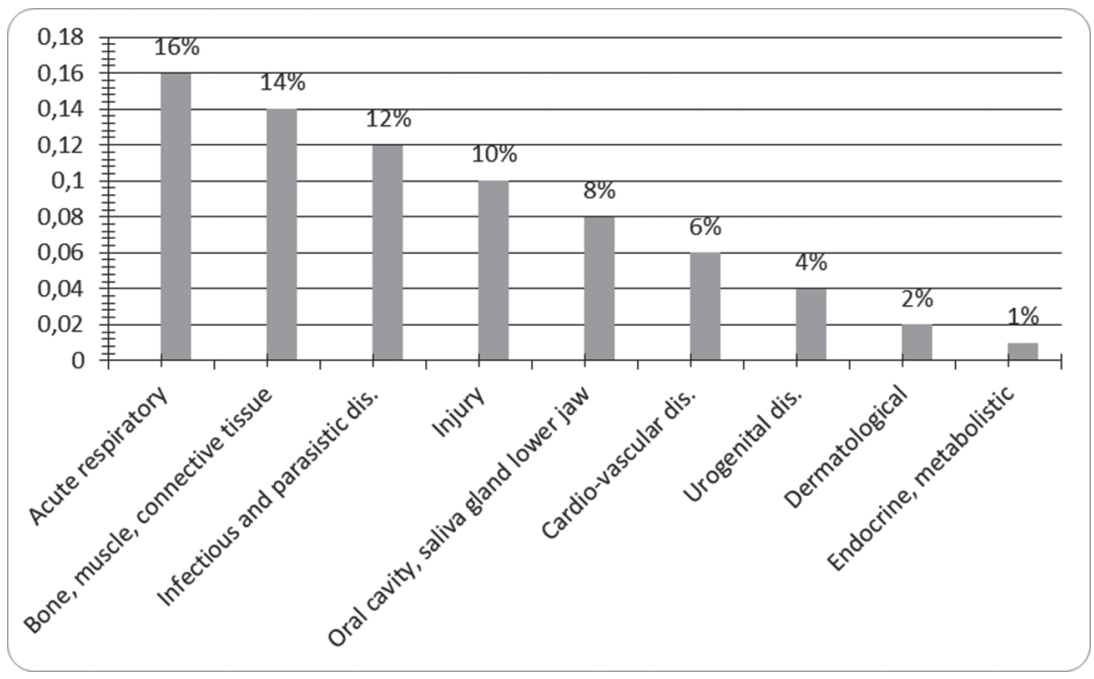

Graph 8. Prevalence of diseases in HDF. [8] 


\section{Force Health Protection Tasks during the Pre-Deployment Period}

Pre-deployment medical training programs are based on medical risk assessment data (evidence based). Health status of deployed personnel is better than the health status of home based personnel (due to strict pre-deployment health, mental and physical screening). The primary prevention on deployments has an emphasized role in assuring mission and combat readiness. In order to minimize the rate of preventable diseases, it is important to provide climate specific training (for prevention of acute respiratory diseases), to develop health oriented and climate specific alimentary practices. Educating on the significance of proper fluid intake, and alcohol and drug prevention is also essential. In the latter case the principle of zero tolerance applies. The tolerable amount of alcohol consumption is declared by mission commanders, and regulated by mission SOPs (Standard Operating Procedures). Training on legal consequences of consuming legal and illegal substances is also part of the pre-deployment education program. To prevent mental disorders and development of combat stress syndrome, a 30-hour psychological training program takes place during the pre-deployment period. [3]

\section{Conclusions}

1. Introduction of the EPIHUN surveillance system provided an opportunity for mission specific pre-deployment training, in order to minimize the proportion of preventable diseases.

2. Distribution of diseases on deployment and at home base does not differ significantly.

3. The high proportion of acute respiratory diseases shows correlation with temperature changes.

4. Training of medical personnel in disease coding can reduce the high incidence of "any other diseases".

\section{Summary}

Continuous monitoring of the health status of military personnel is one of the most important areas of activity for force health protection. The Hungarian real-time surveillance system - called EPIHUN - provides deployment health information on a weekly basis. These data provide important information on the deployed troop's actual health status which can be monitored. Using validated criteria based on standardised definitions, unified methods and procedures, this system allows data collection, analysis, feedback and also intervention, if necessary.

In this article we detailed the EUFOR, KFOR, MFO and the UNFICYP patient turnover data by mission, for the year 2013. These data were analysed to detect changes in incidence (first appearance) and in control examination (second appearance), and also in follow-on specialist medical care. It was found that the morbidity index is associated with the operations geographical environment and climate. Nearly $40 \%$ of all patients suffered from acute respiratory diseases, bone, muscle and connective tissue diseases, and dermatological cases, which were the most frequent cause for seeking medical care. The results are similar to na- 
SVÉD L., SÓTÉR A., VEKERDI Z.: Diseases and Non-Battle Injuries (DNBI) in HUN Missions...

tional epidemiological data. These DBNI cases are preventable. We can determine the type and frequency of diseases, which have the potential to make important and exact recommendations for primary prevention and training in the pre-deployment period. The so-called patient turnover report's data (EPIHUN) provide valuable information on planning the capacity of the medical supply system, organizing the supplies, calculating and estimating the expected disease burden, force health protection and tracking down the capability of military duties.

\section{References}

[1] AMedP-4.1 Deployment Health Surveillance.

[2] Instruction 253/2008 of the Hungarian Surgeon General about casualty data reporting of deployed personnel.

[3] SÓTÉR A., SIMÓ A.: Az afganisztáni misszió egészségügyi kockázatai, a saját csapatok egészségügyi haderővédelme. Felderítő Szemle, IX 3-4 (2010), 165-184.

[4] SÓTÉR A, HORNYÁK B.: A csapategészségügyi rendelők betegforgalmi mutatói 2012. évben. Honvédorvos, LXV 3-4 (2013), 5-14.

[5] SVÉD L.: A Magyar Honvédség egészségügyi biztosítása elvének és gyakorlatának változásai, sajátosságai, különös tekintettel a haderő átalakításra, a NATO-ba történő integrálásra, a különböző fegyveres konfliktusok, valamint a békefenntartó, béketeremtô- és támogató tevékenységre. Budapest: ZMNE, 2003. PhD-értekezés

[6] STANAG 2535 Deployment Health Surveillance.

[7] SVÉD L.: A tervezéstől a múveletig, a katona-egészségügy. Budapest: ZMNE, 2009. Egyetemi tankönyv

[8] Summary of Patient Turnover Report Data from 2013. Budapest: Institute of Health Promotion, Directorate of Force Protection Authority, Military Hospital, Hungarian Defence Forces. 